\title{
A cross-cultural and Intercultural of Indirectness Speect Act: The Use of Interference Local Language in Academic Discourse at Central of Sulawesi
}

\author{
Kasim, F. ${ }^{1}$, Sumarlam ${ }^{1}$, Suwandi, S. ${ }^{1}$, Rakhmawati, A. ${ }^{1}$ \\ ${ }^{1}$ Program Doktoral Pendidikan Bahasa Indonesia Pascasarjana Kependidikan \\ Universitas Sebelas Maret, Surakarta, Indonesia \\ Corresponding email: fatmakasim@student.uns.ac.id
}

\begin{abstract}
Cross-cultural and intercultural communication is a cross-ethnic communication that naturally arises in a social context with different religious, social, ethnic, and linguistic backgrounds. In this case, it is learned how people with different cultural backgrounds interact with each other using their language. One form of communication can be seen from the use of speech acts and the form of interference from the communicant language. This paper aims to describe how the use of Malay Manado local language interference in academic discourse at Alkhairaat Palu University of Central Sulawesi. The method employed to prepare this research is descriptive qualitative method. The data were collected throught observation, recording, and interview. Systematically analyzed by using the descriptive qualitative model of interactive. The results of this study concludes that the Malay Manado local language used in acting speech to ethnic Kaili and Makassar as linguistic features between students. In the speech acts are also colored the use of Manado language interference seen vowel changing / e / and / i /, vowel removal/ e /, and consonant removal / s /, / t /, and / k /. This language varies as a result of cross-cultural and intercultural communication within the academic community in accordance with its social context.
\end{abstract}

Keywords: Cross-cultural; intercultural; speech acts; interference of local language; academic discourse

DOI: http://dx.doi.org/10.20961/ijpte.v1i2.14534 


\section{INTRODUCTION}

Cross-cultural communication is a cross-ethnical communication inside similar (national) cultures, also a communication involves some proceses of influencing, social influence, gender issue influence and preception from the cultural point of view. Cross-cultural communication is defined as a comparing analysis by accentuating the relationship inside the cultural activities. The relationship between cross-cultural communication and multi-cultural communication is focused on the inter-nations relationship without forming a culture. Intercultural communication can happen if there are two different cultures, and both the cultures are performing a communication process (Purwasito: 2015: 122). Next, it is explained the Gudykunst opinion that intercultural communication is also a process of symbolic exchange among individual from at least two cultural communities or more, which negotiate a shared meaning in an interactive situation (Purwasito, 2015: 125). Two individuals from different cultures will communicate with different ways, processes, and communication styles. The flexible and dynamics process of cross-cultural exists in Indonesia, which is seen from the development of language, verbal and arts tradition, a varied language exist in Indonesia is a verbal expression of the diversity of culture of Indonesia nation.

The amount numbers of language in Indonesia have caused the linguistics situation in Indonesia becomes extremely complex, so it can arise this crosscultural and intercultural communication. It is because in their daily activities, Indonesian society uses Bahasa and regional language in speech acting in accordance to the function, situation, and context in using language. In daily life, the combination of Bahasa in Indonesia and regional language promotes the presence of the use of integration forms and the interference of code mixing and code switching of speech act. The presence of code switching and code mixing is the result of the ability of the member of society in using more than one language. Besides that, if there are two languages or more meet the thing will happen is that a such component can be transfered from one language that is source language (or donor language) into the other language, that is recipient language. As the result, there will be interference happened, as defined by Wenreich (1970).

The diversity of local languages in Indonesia, untuk sementara, according to the result of identification of the Language Center (2008), there are 442 local languages. Indonesia's diversity is reflected on the amount of local languages (regional languages) (Mahsun, 2014: 99). Language, besides functions as a communication medium, it also becomes the identity of its speaker. Speaker's identity relates to each ethnic of a group of society. Indirectly, in this study, ethnic/ sub-ethnic is the smalles entity of the speaker of such a language. Ethnic (which is signed by the use of local language/ Mother language) and sub-ethnic (which is signed by the use of dialect/ sub-dialect of this local language) are the smalles communities, which become the target of linguistics study. Through the important roles of a linguistics study, it also can be seen how is a language introduced as an introduction in a community relationship. 
Lumintaintang (2007) stated that this setakat it is strongly felt that the condition of linguistics in our country, which is bilingual/ multilingual and disglosic tends to unstable. It is indicated by a fact that the functions of the languages exist in Indonesia have competed its domain of use. This condition is called as leakage diglossia. Actually, the presence of two languages or more in the society does not has to arise a competition or does not need to be competed by the speakers, either to be used or tobe studied. But, the fact shows that Melayu language, especially Melayu Betawi/ Jakarta dialect and non-standard Bahasa/ slang language, which are grouped into low class, tends to take over the domains of the using of Bahasa in high class, such as in occupational domain, school/ campus, radio, television, or other media. In other words, bilingualism/ multilingualism itself has become the main problem in the use of language.

The condition of communication practice that triggers the presence of between one language and other language, causes the appearance of an interplay relationship between one language and the other language in a such community. At the time a speaker is communicating with his speaking partner, the speaker is doing some changing of the language codes in order to promote such a purpose. Suwito (Hendraryan, 2015: 28) states that code switching is an event of switching a code with other code. This definition promotes an interpretation of a speaker who uses a certain code (for example code A) in the communication practice with his speaking partner, then in other situation does a changing of this code into code $\mathrm{B}$ for a certain purpose and reason, which can also called with code switching.

In bilingualism society, the code switching is also applicable for some language variants where there are regional variant, social class variant, range, style, and dialect inside it. It is in accordance with Wardaugh's (2010: 102) opinion who stated that code switching is a code mixing, that is other switching in a communication, and code mixing is one language in other language in a communication, and language mixing. Communication is the necessary basis of all social interaction, communication is the basis of a social relationship and also as the main thing in develop a culture. Related to the presence of the use of regional language in some interaction generally happened in the society and especially in the academics context, can easily be reviewed a varied code mixing which is done by the speaker itself as purely the speaker's design as one form of indirect cross-cultural communication and cultural (ethnical) relationship in speech acting.

Meanwhile, Leech (1993) stated that the term of speech act does not only refer to speaking action, but refers to the whole communication, including the context of the utterance, that is the situation where the discourse happens, the participants and all verbal or physical interactions happens previously, and also the characteristics of paralinguists which can give some contribution to the meaning of the interaction. Thus, something which is discussed in the speech act theory is a contextualized speech. In this matter, something that bocomes the focus is not whether a speech is right or not according to its grammar, but focuses on whether the speaker sucesses to reach his communication purpose. 
Everyone will process the linguistics situation, and his reciprocal interaction on any different levels depends on each individual. It also can be obtained through verbal academics discourse in a varied forms and strategies in conveying information, so it tends to create an integration of two cultures and languages through either formal or informal lectures interaction, which creates a form of interference of regional language. Based on some studies carried out in different parts of the world with different focus of study, such as the studies carried out by Froese, Peltokorpi and Ko (2012), Aristei and Rahman (2013), Baydak, Schariot, and Il'yashenko (2015), Fomin and Yakimova (2016), Imai and Masuda (2016), Prior et.al (2017), Hassan (2014), Su (2017), Samar and Bhatia (2017), Love (2017), and also Cho and Kim (2017).

Based on the above simple explanation related to the presence of regional culture which can interplay among any languages, the writer formulates the following problems: (1) What is the form of interference of local language in the vowel changing on the speech act among the students? (2) What is the form of interference of local language in the vowel removal on the speech act among the students? (3) What is the form of interference of local language in consonant removal on the speech at among the students? As for the scope of this study is limited on how is the projection of interethnics interaction that promote the occurrence of interference form grammatically on the using of Bahasa in either formal or informal interaction in lectures environment, especially in Bahasa Education Program Study, Tadulako University Palu and Alkhairaat University Palu. Whereas the operational limitation of this study is grammatical interference, which can see the changes of Bahasa as the cause of the local language on the presence of the changing and removal of some vowels, and also the changing and removal of some consonants.

\section{METHOD}

This study is a descriptive qualitative study by reviewing some internal and external factors, which promote the occurence of local language interference to the use of Bahasa in some interaction in Kaili, Manado, and Bugis languages. Whereas the location of this study are Tadaluko University and Alkhairaat University on Bahasa Education Study Program through random sampling, based on the data adequacy. The subjects of this study are the students of Bahasa Education Study Program, Tadaluko University and Alkhairaat University Palu. Source of the data is obtained from some interaction among the students on either formal lectures process or informal, out of lectures time. The data in this study are verbal speech which consist of various using of interference forms of local Central Sulawesi languages (Kaili, Manado, and Bugis).

In collecting data, this study is carried out by using basic technique, that is tapping technique (Sudaryanto, 1993). As a basic technique, it has an advanced technique, that is uninvolved conversation observation technique (teknik simak bebas libat cakap) (Mahsun, 2012: 219). Observation technique by uninvolved conversation observation technique means that the researcher taps the language 
behavior in a certain speech event without his involvement in this speech. The researcher only becomes an observer, who are also taking note for some data which are relevant and doing some recording. The observation consists of some observation activities to the objects of this study. In this observation stage, it is used also field recording technique by recording all speech among the students, where there are some interference forms in a certain local language determined previously inside it. This recording is aimed to filter some speech data more effectively by involving the researcher into the class or lectures, then listing the direct speech types, which are interpreting various forms of local language interference. Besides using observation technique and recording technique in validating the data, it is also done some interview process in order to obtain a data conformity with the purpose pointed by the informants or the objects of this study. Next, in analyzing the data, theoritically this study uses interactive model (Miles and Huberman, 2014: 15 - 20), which consists of four stages, data collecting, data reduction, data analysis, and verification or drawing a conclusion based on the form of interference of the local languages in the use of Bahasa.

\section{RESULT AND DISCUSSION}

\section{Vowel Changing}

Vowels Changing happens on vowels /a/, /e/, and /i/ is the following:

The words kanapa, sadiki, and pigi, in the following sentences are not the baku form in Bahasa. These form of sentences are interferences of vowels changing which come from local languages, that is Manado language and Kaili language. The word form kanapa, sadiki, and pigi is a changing or an influence that charcterizes Manado and Kaili Languages.

\section{Kanapa}

Kanapa? Ngana te masok? Dosen so mau Masuk itu. Ato nga mo ba bolos kah? 'Kenapa? Kamu tidak masuk? Dosen sudah mau masuk itu, atau kamu mau boloskah?’

Ada apa? Apakah kamu tidak ingin masuk? Dosen akan masuk. Ataukah kamu ingin membolos

(What's wrong? Do you not want to come in? The Lecturer will come. Or, do you want to skip?)

The word kanapa comes from the word kenapa, which change vowel $e$ into vowel $a$. This form of vowel changing in baku Bahasa is kenapa. The word kenapa is a questional word to ask a cause or reason. In the above speech data, there are some interferences from Manado and Kaili languages, that is te?, which means do not, and word maso?, which means come into. The interference of word maso?, which means come into is a vowel changing $u$ into $o$ and consonant $k$ into ? (glotal). 


\section{Sadiki}

Sadiki sekali itu Ranga ngana ambe kertas. Banyak dank kita ini! Te mo cukup. Sedikit sekali itu kasian kamu ambil kertas. Banyak kita ini. Tidak mau cukup. Jumlah kertas yang kamu ambil sangat sedikit. Jumlah kita sangat banyak. Tidak akan cukup

(The amount of the paper you have taken is so little. We are too many. It willnot be sufficient.)

The word sadiki comes from word sedikit, it changes vowel $e$ into vowel $a$ and removes consonant $t$. This changing of vowel in baku Bahasa should be sedikit. The word sedikit means not many: just several. Besides that, on the above speech there were some interferences from Manado and Kaili languages, that is word ambe, which means ambil (take) and word ranga, which means kasihan (suppression) and word so which means have been. This interference of sadiki which means sedikit is vowel changing $e$ into $a$ and consonant removal $t$.

\section{Pigi}

Kong so pigi semua panitia KKBS deng oto? Torang bemana ta tinggal?

Jadi sudah pergi semua panitia KKBS dengan mobil? Kita bagaimana yang tertinggal?

Jadi semua panitia KKBS sudah berangkat dengan mobil? Bagaimana dengan kita yang tertinggal

(So, all panitia of KKBS have gone by car? How about us, who were left here?)

Word pigi comes from word pergi, which changes vowel $e$ into vowel $i$ and removes consonant $r$. This form of vowel changing in bahu Bahasa should be pergi. Word pergi means walk (move) forward; leave a certain place; go. At the above speech, there are also interference of Manado language Deng which means dengan (by), So which means sudah (have been), and Torang which means kami (we, the plural form of third personal pronoun). The influence of the above interference shows that the use of local languages, including in using language, gives influence to someone in communicates with others. By using local language, someone will be more capable in communicating the purpose he wants to convey to his speech partners. Similarly, it has been reaffirmed by Holtgraves (1997) that "People differ in terms of whether they express their meanings directly or indirectly and whether they look for indirect meanings in remarks of others. Although many researchers have noted these differences,empirical research on this topic has been rare. This article reports the development and validation of a measure that assesses the production of indirectness (the extent to which a person phrases his or her remarks directly or indirectly) and the comprehension of indirectness (the extent to which a person looks for indirect meaning in the remarks of others)". 


\section{Vowel Removal}

In the data filtering process, it is found some interference of local language in the use of Bahasa that removing some vowels in certain words. This vowels removal can be seen in vowel /e/ and /i/. The following is the review:

Bli

Pa ba bli di kantin saja kita daripada torang tunggu dorang bale.

Pergi beli di kantin saja kita daripada kita tunggu mereka balik.

Sebaiknya kita pergi membeli di kantin sendiri saja,. Daripada kita harus menunggu mereka kembali

(It is better if we go to buy in the canteen by ourself, than we have to wait them back.)

The word bli, on the above data is a vowel removal as the cause of influence that comes from the local language. The word bli is an interference of changing or an influence which has characteristic of Bugis and Kaili languages. This word comes from word beli which means membeli (to buy), to get something through an exchange of money (payment). At the first sentence above, besides the interference of word bli, there is also other interference, that is word bale that removes consonant $k$. The word bale comes from word balik which means kembali (come back) or pulang (come home). Besides that there are some interferences of Manado language, torang which means kita (us) as a form of plural first nominal pronoun and dorang which means dia (they) as a form of plural third personal pronoun.

$\mathrm{Tu}$

Tu dank sana absen. Ngana yang lebe dekat. Nga yang bawa akang ke Ibu.

Itu sana absen. Kamu yang lebih dekat. Kamu yang bawa kan ke Ibu.

Absennya berada di sana. Kamu yang lebih dekat dengan absennya. Кamu yang bawa absennya ke Ibu

(The presence form is there. You are closer to it. You have to bring the presence form to me).

Word $T u$ is a vowel removal $i$ as a cause of the influence of Bugis language. The word $t u$ is word Itu which comes from word itu which means pronoun for a thing or something which placed far from the speaker. Besides that, there are some interferences of Manado languages Ngana which means kamu (you) as a form of second single pronoun, lebe which means more, exceeding such a measure, amount, etc, and word Akang as a suffix kan on the previous word.

\section{Stenga}

Aduh, stenga mati saya angka' ini pe basar.

'Aduh, setengah mati saya angkat barang sebesar ini'.

Aduh, sangat sulit saya mengangkat barang sebesar ini.) 
(Oh, it is so difficult for me to lift this big good up.)

Word stenga on the sentence 3 above is not a standard form of Bahasa. The form of this sentence is a vowel removal $e$ and consonant removal $h$ as a cause of an influence which comes from Kaili and Bugis local language. This word comes from word setengah (a half) which means seperdua. The local language grammar presence in some speech data obove is an approach that opposites with the general grammar that describes a language based on its usage (Hunston in $\mathrm{H}, \mathrm{Su}, 2017$ : 73). The using of local language above, does not see the language structure as it should be, but sees the meaning in accordance with the need of the language users in order that the purpose conveyed is easier to be understood by the speech partner.

\section{Consonant Removal}

In some study in the field, it is also found some using of language from the students that removes some consonant in certain words. The removed consonant are consonant $/ \mathrm{s} /, / \mathrm{t} /$, and $/ \mathrm{k}$. The review is as follow.

\section{Dapa}

Kau dapat dari mana lagi itu jawabanmu ranga?

Kamu dapat darimana lagi itu jawabanmu kasian?

Dari mana kamu dapatkan jawaban itu?)

(From where did you get that answer?)

Word dapa on the first sentence above is not the standard form of Bahasa. The form of this word is a removal of consonant $t$ because of an influence which comes from some local languages, that is Kaili and Manado languages. The word dapa is an interference of changing or influence which has characteristic Kaili and Manado languages. This word comes from word dapat which means mampu (capable); menerima (receive); memperoleh (obtain); menemukan (find); berhasil (success). But, at the context of the above sentence, it means memperoleh (obtain). The word dapa, which means dapat (memperoleh/ obtain) is a form of consonant removal $t$ as a result of interference from Kaili and Manado languages. This form of consonant removal in baku Bahasa is dapat.

$N a E^{\prime}$

Bolehlah kau saja yang nae ke prodi. Bemana?

Bolehlah kamu saja yang naik ke prodi. Bagaimana?

Bagaimana jika kamu saja yang naik (ke) Prodi, apakah bisa?

(How if only you, who go up to the office, can you?)

Word naE is a form of consonant removal $k$ because of an influence which comes from some local languages, that is Kaili and Manado language. The word naE comes from word naik which means move up or to a higher place; arise; climb, 
come into a house (through stairs); drive; by; become higher; increase; become; go to.

Lia'

Boleh kita lia kan mobilnya ibu di depan ruang sekretaris prodi?

Boleh anda liatkan mobilnya ibu di depan ruang sekretaris prodi?

Bolehkah Anda lihatkan mobil Ibu di depan ruangan sekertaris prodi?

(Can you see my car in front of the study program secretary's room?)

Word Lia' is an interference from manado language by removing consonant $t$. The word lia' means lihat (see), which has a meaning using the eyes to view. The influence of Manado language is more often seen used because this language is more often used in various domains, either in family environment, society, or in education environment. The use of this language as an alternative, by considering some ways in developing a unique cultural discourse as a linguistics phenomenon in academics stage, where an individual can internalize his thinking to others as the speech partners (Imai, Kanero, and Masuda, 2016: 72).

\section{CONCLUSION}

Based on some findings of data above, it can be concluded that the use of phonology interference of the students' language using in interacting in formal and informal lectures is colored by some vowels changing, vowels removal, and consonants removal. An example of vowel changing is from word kenapa into kanapa, vowel removal from word setengah into stenga, and consonant removal from word naik into naE, and other examples that have been described previously. The interference frequency based on the origin of local language, the data shows that interference of Kaili and Manado languages still dominates in the use of Bahasa by the students in the formal and informal interaction. An individual factor as the promoter or inhibitor of the occurrence of interference is something related to the speaker as a bilingual. In this bilingual speaker, the language attitude, mastering, and individual language ability will determine the occurrence of the form of interference or integration in using language. Cross-cultural communication will happen when a certain culture gives some messages to the member of the other culture. Precisely, cross-cultural communication involves an interaction between people who have quite different cultural perception and symbolic system in a communication.

\section{REFERENCES}

Aristei, S. And Rahman, R. A. 2013. "Semantic Interference in Language production is due to graded similiarity, not response relevance”. Acta Psycologica 144 (2013) 571-582.

Baydak, A. V., Schariot, C. Il'yashenko, I. A. 2015. "Interaction of Language and Culture in the Process of International Education”. Procedia - Social and Behavioral Sciences 215 (2015) 14-18. 
Cho, M., and Kim, G. 2017. “A cross-cultural comparative analysis of crowdfunding project in the United States And South Korea”. Computer in Human Behavior 72 (2017) 312-320.

Fomin, A. G., and Yakimova, N. S. 2016. "Communication strategies in conflict discourse: crosscultural experimental research”. Procedia - Social and Behavioral Sciences 236 (2016) 65-70.

Froese, F. J., Peltokorpi, V., and Ko, K.A. 2012. "The influence of Intercultural communication on cross-cultural adjustmen and work attitudes: Foreign workers in South Korea”. International Journal of Intercultural Relations 36 (2012) 331-342.

Hassan, Z. M. 2014. “Language Contextualisation and Culture”. Procedia - Social and Behavioral Sciences 136 (2014) 31-35.

Hendraryan., R. 2015. "Ekspresi Kesantunan dalam Tuturan Bahasa Indonesia oleh Penutur Dwibahawasan Sunda-Indonesia”. Disertasi Tidak Diterbitkan: Program Studi Pendidikan Bahasa Indonesia Sekolah Pascasarjana Universitas Pendidikan Indonesia Bandung.

Holtgraves, T. 1997. "Styles of language use: Individual and cultural variability in conversational indirectness” . Journal of Personality and Social Psychology, Vol 73(3), Sep 1997, 624637.

Imai, M., Kanero, J., and Masuda, T. 2016. "The Relation between language, culture, and thought”. Elsiever: Current Opinion in Physhology, 2016, 8:70-77.

Leech,. G. 1993. Prinsip-prinsip Pragmatik. Penerjemah:Dr. M.D.D. Oka, M.Pd. Jakarta: Universitas Indonesia Press.

147.

Love, N. 2017. 2017. “On Languaging and Language”. Language Sciences 61 (2017) 113-

Lumintaintang, Y.B. 2007. “Laras Bahasa Hukum”. Jakarta: Pusat Pembinaan dan Pengembangan Bahasa.

Mahsun. 2012. Metode Penelitian Bahasa: Tahapan Strategi, Metode, dan Tekniknya. Jakarta: Raja Grafindo.

Purwasito, A. 2015. Komunikasi Multikultural. Yogyakarta: Pustaka Pelajar.

Prior, A., Degani, T., Awawdy, S., Yassin. R., and Korem, N. 2017. "Is susceptibility to crosslanguage interference domain spesific?”. Cognition 165 (2017) 10-25.

Samar, R. G., and Bhatia, T., K. 2017. "Pedictability of Language death”. Language Sciences 62 (2017) 52-65

Sudaryanto. 1993. Metode dan Analisis Aneka Teknik Bahasa. Yogyakarta:Duta Wacana University Press.

Su, H. 2017. "Local Grammar of Speech Acts: An exploratory study”. Journal of Pragmatics 111 (2017) 72-83.

Wardaugh, R. 2010. An Introduction to Sociolinguistic. USA: Blackwell Publisher Inc.

Weinreich, U. 1970. Language in Contact: Finding and Problems. The hague: Mauton. 